\title{
Reasons for the Movement of Female Immigrants to the Republic of Turkey: Research and Analysis
}

\author{
Oksana Koshulko \\ Graduate School for Social Research, Institute of Philosophy and Sociology, Polish Academy of \\ Sciences, Warsaw, Poland \\ oksanakoshulko2015@gmail.com
}

Keywords: Movement, Female Immigrants, Republic of Turkey, Marriage

\begin{abstract}
The article presents the results of studies on reasons why female immigrants coming to Turkey as well as basic problems for married female immigrants in Turkey. The article has presented several groups of female immigrants and reasons why female immigrants coming to Turkey. The first group were married female immigrants who gave their reason for coming to Turkey as marriage; the second group were female labor immigrants who came to Turkey seeking work; and the third group were females who wanted to work but they were, or may have been, members or victims of criminal organizations. According to the results of the article, female immigrants face many challenges in the country, within their families and in outside society. Female immigrants, who are considering living in Turkey for any length of time or even for forever, should understand and analyze all possible difficulties and challenges that may arise in their lives in Turkey. At the same time, the country holds wonderful prospects for developing female immigrants and the most important thing is for them to find the means of benefitting from all that is offered.
\end{abstract}

\section{Introduction}

The article has been written using the results of the fellowship project "The migration of women from Ukraine and former Soviet Union countries to Turkey: differences, similarities, and outcomes" conducted during the 2014-2015 academic year at Maltepe University in Istanbul thanks to the Scientific \& Technological Research Council of Turkey (TUBITAK), Ankara, Turkey. The research was conducted in four cities of the country, Izmir, Istanbul, Antalya and Ankara.

The main aim of the article was to explore opportunities for adaptation and integration and the prospects for professional, personal-development and self-employment for female immigrants while considering the positive and negative sides of female migration to Turkey.

The methodology of the article consisted of field research, semi-structured interviews, snowball sampling non-probability (non-random) method, quantitative and qualitative research methods, sociological observation and involvement of expert assessments.

\section{The Previous Research on Female Migration to Turkey}

This subject is very topical and numerous scientists have studied female migration in Turkey, such as Hemmasi M. and Prorok C.V. in their article 'Women's the article 'Migration-driven women's empowerment: The case of Turkey' [1], Bloch A. in her book 'Sex, Love, and Migration. Postsocialism, Modernity, and Intimacy from Istanbul to the Arctic' [2], Yucesahin M. and Yazgan P. in their book 'Revisiting Gender and Migration' [3], Suter B. in the article 'Asylum and Migration Policy in Turkey: An Overview of Developments in the field 1990-2013' [4], as well as other books and papers in this field 'Issues in countries of the former Soviet Union as the driving force for female migration to Turkey' [5]; 'Women from North move to South: Contemporary migration from the Former Soviet Union countries to Turkey' [6]; 'Children of female immigrants in Turkey: numerical analysis of data' [7]; 'Labor Market and Women's rights for female immigrants in Turkey' [8]; 'Challenges of Ukrainian female immigrants and their children in host countries' [9]; 'Slavic women in Turkey: from past to present' [10]; 'Human capital depreciation of female immigrants and ways to restore lost human capital' [11]; 'Exploring What Brings Women to Migrate' [12]; 'Field Studies on 
Female Immigrants in their Host Countries: Challenges and Prospects' [13]; and 'How Human Development in Turkey affects female immigration' [14].

In addition, some researchers have studied the problems of Sex Trafficking and prostitution in Turkey, among them being Coskun E. with her book 'Sex Trafficking in Turkey: Migration Policy, Prostitution and Gender' [15].

\section{The Three Reasons why Female Immigrants Coming to Turkey}

The article looked at the three main groups and reasons that female immigrants give for coming to Turkey.

The first group were married female immigrants who gave their reason for coming to Turkey as marriage. They had succeeded in finding husbands and marriage allowed them to have Turkish passports, residence permits for their family and sometimes work permits in Turkey. The majority of the married female immigrants were willing and able to participate in the research.

The second group were female labor immigrants who came to Turkey seeking work. They were domestic workers, workers in cafés, markets or small shops in the Laleli and Aksaray neighbourhoods of Istanbul. It appeared that the majority of them were working without official work permits and as such were illegal, semi-legal workers or slaves. From time to time, the Turkish police stage raids and arrest some of these immigrants. This means that these women were frightened and had not generally featured in any scientific research or had been categorized incorrectly. These women were much less accessible for research and the majority of them did not want to participate in research.

The third group were females who wanted to work but they were, or may have been, members or victims of criminal organizations. For this reason, these women took no part in this research. Some of them were working on the streets or in hotels in the neighbourhoods of Laleli and Aksaray in Istanbul, as well as in the neighbourhood 'Natasha' in Antalya or other parts of the country. Contact or communication was impossible with them.

Therefore, the first two groups of women took part in the project in the fellowship project. A total of 412 of them were respondents of semi-structured interviews in addition to field research and expert assessments.

\section{The First Group of Women, Who Said that they Came to Turkey Seeking Marriage}

\section{Basic problems for married female immigrants in Turkey}

The majority of married female immigrants in Turkey who participated in this research came from Ukraine, Russia, Belarus and other Russian-speaking countries.

As a rule these women, who had married Turkish men, had a good level of education and wanted to work in Turkey.

All of them had similar or common problems during their adaptation and integration and some of these problems are shown here:

The first problem could be when, or if a Turkish man asks them to convert to Islam before marriage because the Quran, the Islam holy book, says: 'And do not marry polytheistic women until they believe. And a believing slave woman is better than a polytheist, even though she might please you' [16]. If female immigrants convert to Islam they are usually expected to use some form of head covering, as worn by Muslim women, such as a hijab, a headscarf or a burka. An even bigger problem arises if they decide to become apostates after having converted to Islam. Such female immigrants have to be very strong and courageous to take this path because it is very difficult to live in a Muslim society after converting to Islam and then becoming apostate. Some of the women who participated in this fellowship project have done this.

The second problem may arise with the birth of a child, because children born in Turkey to Muslim fathers automatically become Muslims, according to the Rules of Islamic Sharia. According G. Sawma [17]:

- Children Born of Such Marriages are Considered Muslims. 
Under the rules of Islamic Sharia, children born of mixed marriages, involving a Muslim man and non-Muslim woman are considered Muslims. The religion of children born of a Muslim father always follows the religion of their father. It does not matter even if the child is baptized in the Christian faith; he will always be regarded as Muslim and governed by Islamic Sharia.

- Custody of Children in Case of Divorce or Husband's Death.

In the event of divorce, or death of the husband, Islamic Sharia determines that in mixed marriages where the husband is Muslim and the wife is not, the wife will lose her custody to the children'.

The third problem may arise if a wife wishes to work because the majority of Turkish husbands do not want their wife to work. Their husband's Turkish family also does not expect them to work. In the view of their Turkish husbands, they have a fulltime role as housewives or 'Russian wives' (regardless from which country they came to Turkey). The majority of them cannot accept the role of housewife forever, which brings about a crisis in the relationship with their husband and his family. In these cases, the housewife must accept one of two scenarios: either to give up all hope of taking a job and devote their lives to children and family, or to seek a divorce.

If they accept the role of housewife, they join the ranks of the inactive female population in Turkey (from 65 to $62 \%$ of females as a percentage of the total population in the country during 20162018) [18] (Table 1).

Table 1. Inactive population of females as a percentage of the total population in Turkey during 2016-2018 (percentage of females from 15 to 64 years), (\%)

\begin{tabular}{|l|l|l|l|l|l|l|}
\hline Turkey & $2016 \mathrm{Q} 1$ & $2016 \mathrm{Q} 2$ & $2017 \mathrm{Q} 1$ & $2017 \mathrm{Q} 2$ & $2018 \mathrm{Q} 1$ & $2018 \mathrm{Q} 2$ \\
\hline & 65.3 & 63.4 & 63.9 & 62.1 & 62.7 & 61.5 \\
\hline
\end{tabular}

Source: Eurostat, 2018

Table 1 shows that from 2016 to 2018 the percentage of inactive females in Turkey, aged 15 to 64 years old, has decreased from $65,3 \%$ in the first quarter 2016 to $62,7 \%$ in 2018 , but this percentage is still very high compared with other countries.

The fourth problem for the majority of married female immigrants is the lack of access to highquality medical services in Turkey. Therefore, some of them return to their countries of origin to give birth, coming back to Turkey with their newborn children.

The fifth problem for educated female immigrants is when they have the agreement of their husbands, or other Turkish relatives, to work but are unable to find work in their own profession in Turkey. This is usually due to difficulties in obtaining recognition of qualifications from foreign studies and degrees obtained outside Turkey.

According to the data in the monograph 'Women from North move to South: Contemporary migration from the Former Soviet Union countries to Turkey' [6], 'in Turkey, there exists the problem of recognition of academic diplomas of foreigners in general and those of women from the Former USSR in particular. In the host country this procedure of recognition of academic diplomas of foreigners can be done at the Council of Higher Education (CoHE) (in Turkish: Yuksekogretim Kurulu Baskanligl) in the capital of Turkey Ankara, but not all women can complete this procedure of recognition of academic diplomas for a number of reasons:

- because the recognition of academic diplomas can take up to year or more;

- because of the language barrier in cases where applicants need to pass tests or exams in the Turkish language;

- because of lack of support from husbands and/or their relatives in this issue;

- because of periods of maternity leave;

- because of other issues.

Women can also take courses TOMER at the Turkish and Foreign Languages Research and Application Center of Ankara University or in its branches in Istanbul, Trabzon, Giresun, Samsun, 
Marmaris, Izmir, Bursa, Antalya and Alanya that can help them to improve their knowledge of Turkish and so gain recognition of their academic diplomas faster and more easily.

In cases where women do not try to get recognition of their diplomas in the host country and do not try to find a job in their own professions (always supposing their husbands allow them to do so), they can lose their human capital and professional knowledge and skills as time passes.'

The sixth problem may arise at any time within Turkish families, because this concerns violence, abuse, harassment and discrimination towards female immigrants within the family and in Turkish society. During the fellowship project, over $20-25 \%$ of the female immigrants admitted that they have encountered problems of violence, abuse or harassment towards them within their families and in society.

Since 2012 in Turkey the Law to Protect Family and Prevent Violence against Women No. 6284 [19] has been in force, but very few married female immigrants could call on or go to the police seeking protection from violence, abuse or harassment because they are afraid and lonely in Turkey.

In 2015 research into domestic violence against women in Turkey was conducted by Hacettepe University Institute of Population Studies and the Ministry of Family and Social Policies in Ankara. The research was conducted in several difference venues to make it easier for a wider selection of women to be included. This research included 15072 households in various cities and villages from Istanbul, East and West Marmara, Aegean, West Anatolia, Mediterranean, Central Anatolia, West and East Black Sea, Northeast Anatolia to Central East Anatolia and Southeast Anatolia. The research found that within these households 2231 women had been subjected to physical and/or sexual violence by their husbands or partners [20].

Violence in these households could be happening for many reasons, including: 'economic problems and difficulties $(27.0 \%)$; problems with the man's family $(33.0 \%)$; problems relating to the children $(10.2 \%)$, no apparent reason $(11.6 \%)$; pressures from other people $(0.7 \%)$; problems with the woman's family $(3.0 \%)$; bad habits of the man $(11.9 \%)$; reasons relating to the man $(28.3 \%)$; reasons relating to the woman $(24.1 \%)$; gossip $(0.1 \%)$; age difference $(1.1 \%)$; and other reasons $(6.7 \%)^{\prime}[20]$.

Concerning discrimination against female immigrants in host countries, N. Piper and A. French [21] have suggested that female migrants in any host country may face dual discrimination, because they are women and because they are non-citizens in their host country: 'Indeed, gender-based inequalities, injustice, discrimination and outright violence continue to permeate all societies to a certain extent, in some form or another. Such outcomes are often brought to the surface through, or are the result of, the migrant experience which, for women, typically means dual discrimination on the basis of being female and a non-citizen or absent citizen. Yet migration may allow women to turn these negative outcomes around by gaining greater control of their lives, whether through escape from traditional gender roles, improved knowledge and awareness about their rights, or newfound financial independence. Whether they migrate between two societies with opposing or comparable human development situations, women may find that they are liberated simply by having taken on a new role because of the move' [21].

The last of the common basic problems of married female immigrants in Turkey was the lack of opportunity to qualify for the state contributory pension when they are older. If they are not able to work in Turkey while of working age, they will not qualify for a pension.

However, they could join the Individual Pension Savings and Investment System under the Turkish law - 'The Law on Individual Pension Savings and Investment System' No.4632 if they have the opportunity to invest in themselves [22], but very few of the immigrants can do this.

In addition, the Social Security and Social Insurance Law named 'Turkish Social Security and Universal Health Insurance Law' No.5510 [23] and the Act No. 5754 on Social security (general standards) (Act No. 5754, 2008) entitles married female immigrants in Turkey, who become widowed, to receive a portion of the state pension (contributory) according to Article 34 - '50\% shall be payable to the widow spouse; and $75 \%$ to the childless widow spouse, who is put on pension, in case such individual is not put on income or pension due to not working under this Law' [24]. 
Thus, there are many problems that have hindered female immigrants in their integration into Turkish society and into their Turkish families, but these immigrants continue to arrive. Maybe they expect their own story in their new country will be happier than that of their female compatriots.

\section{Stories of how female immigrants met their future Turkish husbands before marriage}

During field research, female immigrants told how they first met their future Turkish husbands. Some of the women met their future husbands in their countries of origin where there were Turkish companies or Turkish workers in other companies, sometimes managers in areas of trade, constructions etc.

Others told of meeting their husbands in Turkey, while on holiday or working in Turkish hotels, or attending weddings of friends or relatives, or via friends or the Internet.

In addition, some of the female immigrants met their future husbands when they came to the country in order to study or as specialists, such as teachers in English.

There were some of the women who were prostitutes before marriage in Turkey. Of course, none of them admitted this openly but their explanations were very unclear and they shied away from questions about their past.

Strategies of survival of married female immigrants who have lived in Turkey for several years

The life of every married female immigrant is different and individual but it is possible to highlight some common features using the results of the fellowship project.

These are a few scenarios:

Some of them can accept the life of married Turkish women, convert to Islam and wear the hijab, headscarf or burka, and devote their life to husband and children;

Some are unable to accept that life and try to find work or study opportunities;

Some chose to divorce and start a new life in Turkey;

Some will take a lover who will keep financially, as part of a survival strategy;

Some will return to their country of origin;

Some will turn to drink and became an alcoholic;

Some are able to found a small business providing services for compatriots in Turkey.

\section{The second Group of Female Immigrants Coming to Turkey to Work}

Many female labor immigrants from Moldova (Transnistria), Georgia (Abkhazia), Uzbekistan, Turkmenistan and other countries, came to Turkey to work and the majority of them do so as undocumented workers. Coskun E. in her chapter 'Undocumented Migrant Women in Turkey: Legislation, Labour and Sexual Exploitation' has studied these issues [3].

The majority of them come using Turkish visas for 30,60 or 90 days, issued according to the Turkish agreements with their countries of origin. They continue to stay after the expiry of their visas. They try to work with compatriots in Georgian or Uzbek cafés, mini-shops, hotels or markets but even so, they may very easily be subject to labor and sexual exploitation.

During the field studies, a Georgian woman told that she came to Turkey with her husband because only this way can they guarantee that she will not become a victim of sexual exploitation.

She came to Turkey because her daughter is sick and she needs money for the treatment. In Georgia, she was a nurse but her salary was so small and treatment for the daughter so expensive that the only way she could see to earn money was to go to Turkey to work.

At the time of this conversation, she was near a prison for illegal immigrants where her husband was being kept, having been arrested during a raid by Turkish police in the illegal immigrant neighbourhoods of Laleli and Aksaray in Istanbul. She was waiting for her husband to be freed.

The life of undocumented female labor immigrants in Istanbul is difficult. The majority of them are frightened and unfriendly. They have never featured in other scientific research or they have been categorized incorrectly. Therefore, they were much less accessible for research compared with married female immigrants. The majority of them categorically did not want to participate in any research. 


\section{The Third Group of Female Immigrants Coming to Turkey}

This group of women come to work with criminal elements in the country and no contact or communication is possible with these criminalized female immigrants in Turkey, Coskun E. in her book 'Sex Trafficking in Turkey: Migration Policy, Prostitution and Gender' [15] and Bloch A. in her book 'Sex, Love, and Migration. Postsocialism, Modernity, and Intimacy from Istanbul to the Arctic' [2] have studied these cases.

\section{Conclusions}

Turkey is generally a multi-cultural and prosperous country but at the same time has many difficulties, restrictions and barriers for Turkish women and especially female immigrants.

This article shows that female immigrants face many challenges in the country, within their families and in outside society. They should be aware of the majority of these problems before they decide to migrate to Turkey.

Female immigrants, who are considering living in Turkey for any length of time or even for forever, should understand and analyze all possible difficulties and challenges that may arise in their lives in Turkey. Different reasons for migration can engender different problems, with different solutions, so each woman must look at her own circumstances. They should weigh up the pros and cons before they make the choice.

At the same time, the country holds wonderful prospects for developing female immigrants and the most important thing is for them to find the means of benefitting from all that is offered.

\section{Conflict of Interest}

The author declares that there is no conflict of interest.

\section{References}

[1] M. Hemmasi, C.V. Prorok, Women's migration and quality of life in Turkey, Geoforum. 33(3) (2002) 399-411.

[2] A. Bloch, Sex, Love, and Migration. Postsocialism, Modernity, and Intimacy from Istanbul to the Arctic, Cornell University Press, 2017, 272 p.

[3] M. Yucesahin, P. Yazgan, Revisiting Gender and Migration, Transnational Press London, 2017, $156 \mathrm{p}$.

[4] B. Suter, Asylum and Migration Policy in Turkey: An Overview of Developments in the field 1990-2013. MiM Working Paper Series, 13 (2013) 3, Malmo Institute for Studies of Migration, Diversity and Welfare (MIM), Malmo University, Malmo, Sweden.

[5] O. Koshulko, Issues in countries of the former Soviet Union as the driving force for female migration to Turkey, International Letters of Social and Humanistic Sciences. 56(2015)120-126.

[6] O. Koshulko, Women from North move to South: Contemporary migration from the Former Soviet Union countries to Turkey, Transnational Press London Ltd., UK, 2016, 126 p.

[7] O. Koshulko, Children of female immigrants in Turkey: numerical analysis of data, World Scientific News. 90 (2017) 88-100.

[8] O. Koshulko, Labor Market and Women's rights for female immigrants in Turkey, in: Proceedings of the International Conference "Black Sea Regional Cooperation: Opportunities and Challenges," Dimitrie Cantemir Christian University, Bucharest, Romania, November 2-3, 2017, pp. 52-53.

[9] O. Koshulko, V.Kobets, Challenges of Ukrainian female immigrants and their children in host countries, in: Proceedings of the 9th Junior Researchers Conference on European and National context in research, Polotsk State University, Novopolotsk, Belarus, April 25-26, 2017, pp.110113. 
[10] O. Koshulko, Slavic women in Turkey: from past to present, in: Proceedings of the 7th International Symposium "Gecmisten Gunumuze Goc - Migration from Past to Present," organized by Canik Municipality together with History Studies Journal, Canik, Samsun, Turkey, February 17-19, 2017, pp. 2117-2124.

[11] O. Koshulko, Human capital depreciation of female immigrants and ways to restore lost human capital, MEST Journal. 6(1) (2018) 27-33. DOI: 10.12709/mest.06.06.01.04

[12] O. Koshulko, Exploring What Brings Women to Migrate, in: Proceedings of the 10th Junior Researchers Conference on European and National context in research, Polotsk State University, Novopolotsk, Belarus, May 10-11, 2018, pp. 142-144,.

[13] O. Koshulko, Field Studies on Female Immigrants in their Host Countries: Challenges and Prospects. Proceedings of the International Scientific Conference "Management 2018", Faculty of Business and Industrial Management, "UNION - Nikola Tesla" University, Belgrade, Serbia, May 4-5, 2018, pp. 67-69.

[14] O. Koshulko, How Human Development in Turkey affects female immigration. Proceedings of the XII International Conference "Modernization of the economic mechanism through the prism of economic, legal, social and engineering approaches," Belarusian National Technical University, Minsk, Belarus, March 15, 2018, pp. 62-63.

[15] E. Coskun, Sex Trafficking in Turkey: Migration Policy, Prostitution and Gender, I.B.Tauris \& Co Ltd., 2017, 256 p.

[16] Quran. Surah Al-Baqarah [2:221]. Available: http://quran.com/2/221. Accessed: 28 September 2018.

[17] G. Sawma, Muslim Men Marrying Non-Muslim Women. (2013). International Law. Available: http://gabrielsawma.blogspot.com/2013/07/muslim-men-marrying-non-muslimwomen_5.html. Accessed: 25 August 2018.

[18] Eurostat. Inactive population as a percentage of the total population, by sex and age. Available: http://appsso.eurostat.ec.europa.eu/nui/submitViewTableAction.doc. Accessed: 29 September 2018.

[19] Parliament of Turkey. The Law to Protect Family and Prevent Violence Against Women. Law No. 6284 from 8 March 2012. Available: http://www.lawsturkey.com/law/law-to-protectfamily-and-prevent-violence-against-woman-6284. Accessed: 26 September 2018.

[20] Research on Domestic Violence against Women in Turkey. Hacettepe University Institute of Population Studies, Ministry of Family and Social Policies, Ankara, Turkey. Available: http://www.hips.hacettepe.edu.tr/eng/violence2014.shtml. Accessed: 28 September 2018.

[21] N. Piper, A. French, Do Women Benefit from Migration? An Editorial Introduction. Special issue "Female Migration Outcomes: Human Rights Perspectives." Diversities. 13 (2011) 1-3.

[22] The Law on Individual Pension Savings and Investment System No.4632 (Date of Ratification 28 March 2001. Date of Publication 7 April 2001). Available: http://www.sigortadenetim.org/mevzuat/ngilizce-mevzuat/118.html. Accessed: 18 September 2018.

[23] Social Security and Social Insurance Law. Turkish Social Security and Universal Health Insurance Law No.5510 (The date of enactment of the Law was 31 May 2006, and the date of entry into force was 01 October 2008). Available: http://turkishlaborlaw.com/turkish-socialsecurity-law-no-5510. Accessed: 8 September 2018.

[24] Act No. 5754 on Social security (general standards). (2008). Act No. 5754. Resmi Gazete, 2008-05-08, No. 26870, p. 1-74. Available: http://www.ilo.org/dyn/natlex/natlex4.detail?p_lang=en\&p_isn=79805. Accessed: 10 September 2018. 